\title{
Pleural Mesothelioma pT1a TNM Finding v7
}

National Cancer Institute

\section{Source}

National Cancer Institute. Pleural Mesothelioma pT 1a TNM Finding v7. NCI Thesaurus. Code $C 88901$.

Pleural mesothelioma with no involvement of the visceral pleura. (from AJCC 7th Ed.) 